\title{
PENGARUH MODEL DISCOVERY LEARNING BERBASIS PENDEKATAN SAINTIFIK TERHADAP HASIL BELAJAR SISWA KELASX PADA MATERILISTRIK DINAMIS SMA NEGERI 14 MEDAN T.P. 2014/2015
}

\author{
Yosi Farah dan Ratna Tanjung \\ Jurusan Fisika FMIPA Universitas Negeri Medan \\ yosifarah17@gmail.com
}

\begin{abstract}
ABSTRAK
Penelitian ini bertujuan untuk mengetahui pengaruh model discovery learning berbasis pendekatan saintifik terhadap hasil belajar fisikapada materi listrik dinamis di SMA Negeri 14 Medan. Jenis penelitian ini adalah quasi eksperimen. Populasi dalam penelitianadalah seluruh siswa kelas $\mathrm{X}$ yang terdiri dari 9 kelas.Pengambilan sampel dilakukan dengan cara cluster random sampling dengan mengambil 2 kelas dari 9 kelas dengan teknik undian yaitu kelas X-4 sebagai kelas eksperimen dengan siswa berjumlah 35 orang dan kelas $\mathrm{X}-7$ sebagai kelas kontrol dengan siswa berjumlah berjumlah 33 orang. Hasil penelitian menunjukkan nilai rata-rata postes kelas eksperimen 71,71 dan kelas kontrol 54,54. Kesimpulan dari penelitian ini yaitu ada pengaruh penggunaan model discovery learning berbasis pendekatan saintifik terhadaphasilbelajar fisika siswapadamateri pokok listrik dinamis di kelas X semester II SMAN14 Medan T.P. 2014/2015.
\end{abstract}

Kata kunci :discovery learning, pendekatan saintifik, quasi eksperimen, cluster random sampling.

\begin{abstract}
This research aims to knows the effect of discovery learning based scientific approach model on learning outcomes of physics on subject the dynamic electrical in SMAN 14 Medan. This research is a quasi experimental. Population in thisresearch were all students of class $X$ which consists of 9 classes. Sampling was done by cluster random sampling by taking two classes of ninth grade with lottery technique that is class $X-4$ as the experimental class with 35 students and $X-7$ as the control class with 33 students. The results showed the average value of posttest experimental class is 71.71 and control class is 54.54. Conclution of this research that there is the effect of the use of discovery learning based scientific approach model on learning outcomes of students in the subject physics dynamic electrical in the class X II SMAN 14 Medan T.P. 2014/2015.
\end{abstract}

Keywords : discovery learning, scientific approach, quasi experimental, cluster random sampling

\section{PENDAHULUAN}

Pendidikan memegang peranan sangat penting bagi kehidupan manusia. Melalui pendidikan, manusia akan tumbuh dan berkembang sebagai pribadi yang utuh. Pendidikan juga berperan dalam mempersiapkan manusia yang berkualitas bagi pembangunan negara. Pendidikan merupakan salah satu aset masa depan yang menentukan maju mundurnya suatu bangsa oleh sebab itu pembangunan sektor pendidikan harus menjadi prioritas.

Mengingat pentingnya peranan pendidikan, pemerintah telah 
melakukan banyak perbaikan untuk meningkatkan mutu pendidikan dalam berbagai jenis dan jenjang. Seperti salah satunya dengan mengganti kurikulum.Kurikulum yang masih digunakan dalam pendidikan saat ini yaitu Kurikulum Tingkat Satuan Pendidikan (KTSP) dan Kurikulum 2013 yang memiliki kelebihan masingmasing. Jiwa dari kurikulum 2013 yang sangat berguna bagi proses pembelajaran yaitu pendekatan saintifik.Pembelajaran fisika dengan pendekatan saintifik lebih menyenangkan. Siswa dapat menemukan sendiri konsep-konsep fisika melalui penelitian ilmiah selayaknya seorang ilmuwan.

Hasil studi pendahuluan yang dilakukan peneliti pada 27 Januari 2015 dengan menggunakan instrumen angket yang disebarkan ke 40 responden di kelas X SMA Negeri 14 Medan menunjukkan 60\% (24 orang) menyatakan bahwa pembelajaran fisika di kelas sulit dipahami dan kurang menarik dengan alasan banyaknya rumus-rumus dan hitungan yang sulit dipahami, $52,5 \%$ (21 orang) siswa jarang mengulang pelajaran fisika yang telah dipelajarinya, $70 \%$ (28 orang) siswa menyatakan bahwa pembelajaran fisika yang selama ini berlangsung di kelasnya dengan mengerjakan soalsoal, $17,5 \%$ (7 orang) siswa yang menyatakan dengan berdiskusi, dan $12,5 \%$ (5 orang) lainnya menyatakan mencatat materi. Melalui angket diketahui pula ada sebanyak 15\% (6 orang) siswa tidak pernah mencatat kembali materi yang diajarkan, 52,5\% (21 orang) siswa takut mengerjakan soal ke depan kelas dengan alasan takut dimarahi jika salah, 25\% (10 orang) siswa tidak pernah mengikuti kegiatan belajar fisika di luar jam pelajaran sekolah, dan 92,5\% (37 orang) siswa menyatakan tidak pernah melakukan kegiatan praktikum di laboratorium.

Hasil wawancara dengan salah seorang guru fisika di SMA Negeri 14
Medan, mengatakan bahwa ia jarang membawa siswa ke laboratorium, karena sarana prasarana kurangmemadai dan waktu yang kurang efisien. Model pembelajaran yang digunakan guru adalah model pembelajaran langsung. Kompetensi Minimal (KKM) di sekolah tersebut untuk mata pelajaran fisika adalah 75 . Namun, rata-rata nilai fisika yang diperoleh siswa kurang memuaskan atau dapat dikatakan banyak yang tidak mencapai KKM.

Berdasarkan hasil studi pendahuluan menggunakan angket dan wawancara dapat disimpulkan bahwa proses pembelajaran tidak berpusat pada siswa, yang mengakibatkan siswa berperan tidak aktif dalam memperoleh pengetahuan. Dalam pembelajaran siswa bersifat menjadi pendengar saja dan guru yang bersifat dominan (teacher centered). Dominasi guru dalam pembelajaran ini menyebabkan siswa lebih banyak menunggu sajian dari guru daripada menemukan sendiri pengetahuannya. Oleh karena itu, untuk mengatasi hal tersebut perlu digunakan suatu model pembelajaran yang berpusat pada siswa(student centered).

Berdasarkan masalah di atas, salah satu model pembelajaran yang dapat digunakan adalah model discovery learning. Menurut Hosnan (2014) pada pembelajaran penemuan (discovery) siswa didorong untuk terutama belajar sendiri melalui keterlibatan aktif dengan konsepkonsep dan prinsip-prinsip. Guru mendorong siswa agar mempunyai pengalaman dan melakukan eksperimen dengan memungkinkan mereka menemukan prinsip-prinsip dan konsep-konsep bagi diri mereka sendiri. Siswa juga bisa belajar berpikir analisis dan mencoba memecahkan sendiri masalah yang dihadapinya. Kebiasaan ini akan ditransfer dalam kehidupan bermasyarakat.Menurut Dahar (1989) pengetahuan yang diperoleh dengan belajar penemuan 
menunjukkan beberapa kebaikan. Pertama,pengetahuan itu bertahan lama atau lama dapat diingat, atau lebih mudah diingat bila dibandingkan dengan pengetahuan yang dipelajari dengan cara-cara lain. Kedua, hasil belajar penemuan mempunyai efek transfer yang lebih baik daripada hasil belajar lainnya. Ketiga, belajar penemuan meningkatkan penalaran siswa dan kemampuan untuk berpikir secara bebas. Secara khusus belajar penemuan melatih keterampilanketerampilan kognitif siswa untuk menemukan dan memecahkan masalah tanpa pertolongan orang lain.

Penelitian ini bertujuan untuk mengetahui pengaruh penggunaan model discovery learning berbasispendekatan saintifik pada materi listrik dinamis terhadap hasil belajar fisika siswa kelas $\mathrm{X}$ SMANegeri14 Medan T.P. 2014/2015.Dengan pembelajaran discoverydiharapkan siswa belajar aktif dengan menemukan sendiri, menyelidiki sendiri, maka hasil yang diperoleh akan setia dan tahan lama dalam ingatan, tidak mudah dilupakan siswa.

\section{METODE PENELITIAN}

Penelitian ini dilakukan di SMA Negeri 14 Medan Jl. Pelajar Timur Ujung Gg. Darmo Medan pada bulan April sampai Mei 2015.

Populasi dalam penelitian adalah seluruh siswa kelas X SMA Negeri 14 Medan T.P 2014/2015 yang terdiri atas 9 kelas. Pengambilan sampel dilakukan dengan cara cluster random sampling dengan mengambil 2 kelas dari 9 kelas dengan teknik undian yaitu kelas X-4 sebagai kelas eksperimen dengan siswa berjumlah 35 orang diajarkan dengan model discovery learning berbasis pendekatan saintifik dan kelas $\mathrm{X}-7$ sebagai kelas kontrol dengan siswa berjumlah berjumlah 33 orang diajarkan dengan pembelajaran konvensional.
Jenis penelitian yang digunakan adalah quasi eksperimen. Desain penelitian ini adalah noneqivalent control group designDesain penelitian ini dapat dilihat pada Tabel 1.

Tabel 1.noneqivalent control

\begin{tabular}{|l|c|c|c|}
\hline \multicolumn{1}{|c|}{ groupdesign } \\
\hline Kelas & Pretes & Perlakuan & Postes \\
\hline Eksperimen & $\mathrm{T}_{1}$ & $\mathrm{X}$ & $\mathrm{T}_{2}$ \\
\hline Kontrol & $\mathrm{T}_{1}$ & - & $\mathrm{T}_{2}$ \\
\hline
\end{tabular}

Keterangan :

$\mathrm{T}_{1}=$ Tes awal (Pre-tes)

$\mathrm{T}_{2}=$ Tes akhir (Post-tes)

$\mathrm{X}=$ Pembelajaran dengan modeldiscovery learning berbasis pendekatan saintifik pada materi listrik dinamis.

Pengumpulan data dalam penelitian ini dilakukan dengan beberapa metode yaitu : metode observasi dan metode tes. Instrumen merupakan alat pengambil data untuk mengungkapkan peningkatan hasil belajar dan aktivitas siswa. Instrumen yang dipersiapkan antara lain: perangkat pembelajaran, lembar pengamatan, dan tes essay berjumlah 7 soal. Sebelum data diolah menggunakan uji t untuk mengetahui pengaruh model pembelajaran discovery learning berbasis pendekatan saintifik terlebih dahulu dilakukan penilaian pretes, uji normalitas (uji Lilliefors) dan uji homogenitas (uji F).

\section{HASIL DAN PEMBAHASAN}

Hasil tes yang telah dilakukan di SMA Negeri 14 Medan diperoleh data pretes untuk kelas eksperimen dengan jumlah siswa 35 orang memperoleh nilai rata-rata pretes sebesar 23,43 dengan nilai tertinggi adalah 40 dan nilai terendah adalah 10 . Untuk kelas kontrol dengan jumlah siswa 33 orang memperoleh nilai rata-rata pretes sebesar 23,03 dengan nilai tertinggi adalah 35 dan nilai terendah adalah 10 . 
Data yang diperoleh ditunjukkan pada Tabel 2.

Tabel 2. DataNilai Pretes Kelas Eksperimen dan Kelas Kontrol

\begin{tabular}{|c|c|c|c|c|c|}
\hline \multicolumn{3}{|c|}{$\begin{array}{l}\text { Data nilai pretes } \\
\text { kelas eksperimen }\end{array}$} & \multicolumn{3}{|c|}{$\begin{array}{c}\text { Data nilai pretes } \\
\text { kelas kontrol }\end{array}$} \\
\hline Nilai & $\begin{array}{l}\text { Frek } \\
\text { uensi }\end{array}$ & $\begin{array}{l}\text { Rata- } \\
\text { rata }\end{array}$ & Nilai & $\begin{array}{c}\text { Frek } \\
\text { uens } \\
\text { i }\end{array}$ & $\begin{array}{l}\text { Rata } \\
\text {-rata }\end{array}$ \\
\hline 10 & 4 & \multirow{8}{*}{23,43} & 10 & 3 & \multirow{8}{*}{$\begin{array}{c}23,0 \\
3\end{array}$} \\
\hline 15 & 6 & & 15 & 4 & \\
\hline 20 & 7 & & 20 & 8 & \\
\hline 25 & 6 & & 25 & 9 & \\
\hline 30 & 6 & & 30 & 6 & \\
\hline 35 & 4 & & 35 & 3 & \\
\hline 40 & 2 & & & & \\
\hline Jlh & 35 & & Jlh & 33 & \\
\hline
\end{tabular}
siswa kelas eksperimen dan kontrol lebih jelasnya divisualisasikan dalam diagram batang pada Gambar 1 .

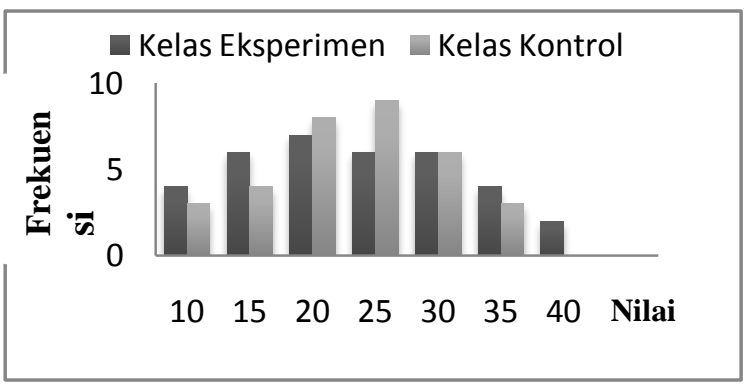

Gambar 1. Diagram batang data pretes siswa kelas eksperimen dan kontrol

Datapostes untuk kelas eksperimen dengan jumlah siswa 35 orang memperoleh nilai rata-rata postes sebesar 71,71 dengan nilai tertinggi adalah 85 dan nilai terendah adalah 60. Untuk kelas kontrol dengan jumlah siswa 33 orang memperoleh nilai rata-rata postes sebesar 54,54 dengan nilai tertinggi adalah 70 dan nilai terendah adalah 40. Data yang diperoleh ditunjukkan pada Tabel 3.dibawah ini.
Tabel 3.Data Nilai Postes Kelas

Eksperimen dan Kelas Kontrol

\begin{tabular}{|c|c|c|c|c|c|}
\hline \multicolumn{3}{|c|}{$\begin{array}{c}\text { Data nilai postes kelas } \\
\text { eksperimen }\end{array}$} & \multicolumn{3}{|c|}{$\begin{array}{c}\text { Data nilai postes kelas } \\
\text { Kontrol }\end{array}$} \\
\hline Nilai & $\begin{array}{c}\text { Frek } \\
\text { uens } \\
\text { i } \\
\end{array}$ & $\begin{array}{l}\text { Rata- } \\
\text { rata }\end{array}$ & Nilai & $\begin{array}{c}\text { Frek } \\
\text { uens } \\
\text { i }\end{array}$ & $\begin{array}{l}\text { Rata- }^{-} \\
\text {rata }\end{array}$ \\
\hline 60 & 6 & \multirow{7}{*}{71,71} & 40 & 3 & \multirow{7}{*}{54,54} \\
\hline 65 & 4 & & 45 & 4 & \\
\hline 70 & 9 & & 50 & 6 & \\
\hline 75 & 7 & & 55 & 9 & \\
\hline 80 & 6 & & 60 & 5 & \\
\hline \multirow[t]{2}{*}{85} & 3 & & 65 & 3 & \\
\hline & & & 70 & 3 & \\
\hline $\begin{array}{c}\text { Jumla } \\
\mathrm{h}\end{array}$ & 35 & & $\begin{array}{c}\text { Jumla } \\
\mathrm{h}\end{array}$ & 33 & \\
\hline
\end{tabular}

Distribusi frekuensi data postes siswa kelas eksperimen dan kontrol lebih jelasnya divisualisasikan dalam diagram batang pada Gambar 2 .

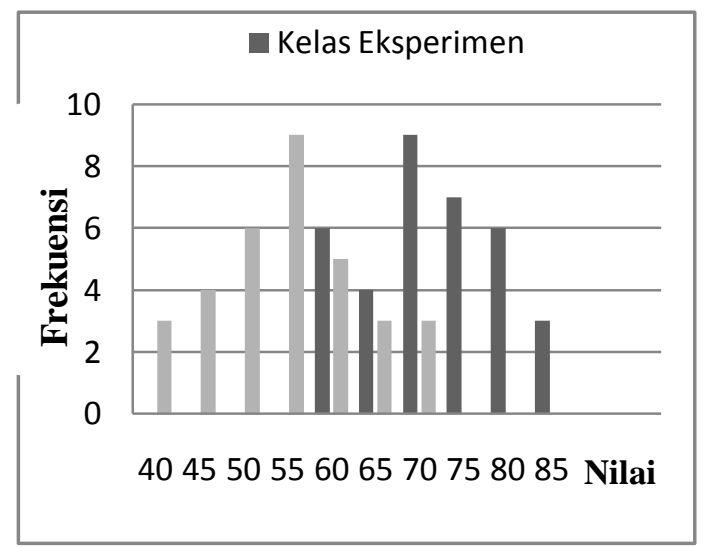

Gambar 2.Diagram batang data postes siswa kelas eksperimen dan kontrol

\section{PEMBAHASAN}

Hasil penelitian menunjukkan bahwa ada pengaruh yang signifikan menggunakan model discovery learning berbasis pendekatan saintifik terhadap hasil belajar fisika pada materi pokok listrik dinamis di kelas $\mathrm{X}$ semester II SMA Negeri 14Medan T.P. 2014/2015.

Hal ini diperkuat dengan perolehan nilai rata-rata pretes siswa di kelas eksperimen sebesar 23,43 dengan standar deviasi8,72 dan nilai rata-rata postes sebesar 71,71 dengan standar deviasi 7,76. Sedangkan di kelas 
kontrol diperoleh nilai rata-rata pretes siswa sebesar 23,03 dengan standar deviasi7,06 dan nilai rata-rata postes sebesar 54,54 dengan standar deviasi8,51. Berdasarkan analisis data pretes dan postes diperoleh soal yang tersulit yaitu soal no.1. Banyak siswa yang tidak dapat menjawab soal tersebut dikarenakan siswa belum memahami konsep beda potensial dan arus listrik secara benar. Meskipun hasil belajar yang diperoleh siswa dengan model discovery learning berbasis pendekatan saintifik belum mencapai nilai KKM yang ditentukan, tetapi hasil belajar siswa yang diberi perlakuan model discovery learning berbasis pendekatan saintifik lebih baik daripada hasil belajar siswa pada pembelajaran konvensional. Nilai hasil belajar siswa yang belum mencapai KKM dikarenakan siswa belum terbiasa belajar dengan menggunakan model discovery learning yang lebih banyak menuntut siswa belajar sendiri. Selain itu nilai KKM yang tinggi belum sejalan dengan daya dukung pembelajaran meliputi kemampuan siswa yang belum mampu mempelajari kompleksitas materi dan kemampuan guru mengingat peneliti belum cukup berpengalaman mengajar dan mendidik siswa.

Selama pelaksanaan penelitian diperoleh bahwa model discovery learning berbasis pendekatan saintifik menguntungkan karena dapat mendorong siswa untuk berpikir ilmiah dan merumuskan hipotesisnya sendiri, siswa dapat menjadi pembelajar aktif yang menghasilkan pengetahuan dan keterampilan yang diperoleh bukan dari hasil mengingat seperangkat fakta-fakta, melainkan hasil dari menemukan sendiri melalui eksperimen. Berusaha sendiri menemukan pemecahan masalah dan pengetahuan yang menyertainya menghasilkan pengetahuan yang benar-benar bermakna dan bertahan lama.

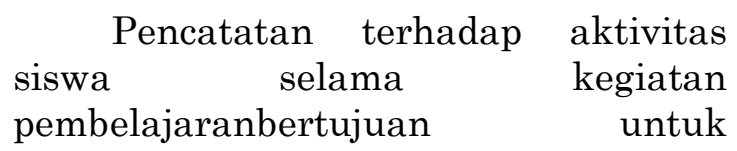
mengetahui seberapa besar keaktifan siswa selama kegiatan belajar mengajar berlangsung.Dari hasil pengamatan yang dilakukan observer diperoleh bahwa aktivitas siswa mengalami peningkatan yang positif. Pada pertemuan I rata-rata aktivitas siswa diperoleh sebesar $54,2 \%$. Hal ini terjadi karena siswa belum terbiasa dengan model discovery learninghingga instruksi dan arahan yang diberikan peneliti kurang dimengerti oleh beberapa siswa. Oleh karena itu, peneliti terus memberikan instruksi dan arahan kepada siswa hingga siswa paham melaksanakan tugas kelompok dan tanggung jawab mereka dalam pembelajaran ini.Pada pertemuan II, diperoleh peningkatan yang positif terhadap aktivitas siswa dengan nilai rata-rata $67,6 \%$ dan pada pertemuan III diperoleh rata-rata aktivitas siswa sebesar $80,1 \%$. Hal ini karena siswa sudah memahami tugas dan tanggung jawab mereka dalam pembelajaran ini, dimana peneliti terus memberikan arahan kepada siswa dan diperoleh rata-rata nilai keseluruhan aktivitas belajar siswa adalah $67,3 \%$ yang termasuk kategori aktif. Ternyata aktivitas siswa yang dikategorikan aktif sejalan dengan peningkatan hasil belajar siswa yang juga dikategorikan baik yaitu 71,71. Dalam hal ini, aktivitas siswa memiliki pengaruh positif terhadap hasil belajar.

Hasil penilaian lembar kegiatan siswa diperoleh persentase skor kelompok siswa pada LKS I sebesar $52,6 \%$ dengan kategori kurang baik. Hal ini dikarenakan siswa masih belum terbiasa belajar dengan model pembelajaran discovery learning yang peneliti gunakan. Pada LKS II sebesar $76 \%$, dan pada LKS III sebesar $82,6 \%$ dengan kategori baik. Hal ini dikarenakan siswa sudah mulai bisa beradaptasi dan nyaman belajar dengan model pembelajaran discovery 
learning. Persentase skor kelompok siswa tiap pertemuan mengalami peningkatan, artinya siswa sudah memahami materi yang diberikan peneliti dalam pembelajaran.

Model pembelajaran merupakan salah satu aspek penting yang mempengaruhi hasil belajar siswa. Jika model pembelajaran yang digunakan dalam mengajarkan suatu materi pelajaran itu tepat, hasil belajar siswa juga cenderung lebih baik. Dari hasil pengamatan peneliti selama melaksanakan penelitian, tampak bahwa semangat siswa yang diajar dengan model discovery learning berbasis pendekatan saintifik lebih baik jika dibandingkan dengan kelompok siswa yang diajar dengan menggunakan pembelajaran konvensional. Hal tersebut dapat dilihat dari hasil belajar siswa dan keaktifan siswa saat proses pembelajaran berlangsung. Model discovery learning berbasis pendekatan saintifik ini dapat membuat siswa menjadi pembelajar aktif saat pelaksanaan proses pembelajaran.

Hasil penelitian ini juga sesuai dengan hasil penelitian yang telah dilakukan oleh beberapa peneliti sebelumnya. Widiadnyana, dkk. (2014) menyatakan bahwa perbedaan nilai rata-rata pemahaman konsep dan sikap ilmiah siswa yang signifikan antara kelompok siswa yang belajar dengan model discovery learning dengan kelompok siswa yang belajar dengan model pengajaran langsung. Yurahly, dkk. (2012) juga menyatakan berdasarkan hasil penelitian dan analisis data disimpulkan bahwa ada perbedaan rata-rata hasil belajar fisika siswa yang mengikuti model pembelajaran guideddiscovery berbasis keterampilan proses sains pada kelas X SMA Negeri 4 Palu. Diperoleh skor hasil belajar rata-rata pada kelas eksperimen lebih tinggi 1,3 atau 6,7\% dari skor hasil belajar rata-rata kelas kontrol.
Model discovery learning mengajak siswa berusaha sendiri menemukan pemecahan masalah dan pengetahuan yang menyertainya sehingga menghasilkan pengetahuan yang benar-benar bermakna Hal ini juga dibuktikan oleh penelitian Indarti, dkk. (2013) bahwa kemampuan memecahkan masalah siswa yang pembelajarannya menggunakan model discovery learning lebih baik daripada model pembelajaran konvensional. Carin and Sund (1964) mengatakan bahwa "....learning by discovery in problem solving is more enduring, meaningful, and useful than learning that has come about by telling....." Pembelajaran dengan penemuan pada pemecahan masalah lebih tahan lama, bermakna, dan berguna dari pada pembelajaran dengan ceramah. Menurut Carin and Sund tujuan mendasar dari pembelajaran penemuan adalah untuk mendekati siswa pada pemecahan masalah dengan faktafakta, materi, dan peristiwa untuk membimbing mereka pada cara mereka sendiriuntuk keluar dari masalah itu dengan membangun generalisasi atau prinsip-prinsip.

Walaupun penggunaan model pembelajaran discovery learningdapat meningkatkan hasil belajar dan aktivitas siswa, tetapi selama pembelajaran masih ada kendala yang dihadapi peneliti yang menyebabkan pencapaian hasil belajar belum maksimal. Pada fase stimulation peneliti tidak bisa menyajikan fenomena dengan media animasi yang telah disediakan dikarenakan keterbatasan sarana dan prasarana, maka peneliti hanya menggunakan fenomena yang disajikan pada LKS sehingga siswa sulit untuk membuat rumusan masalah dan hipotesis (fase problem statement) dengan hanya menggunakan LKS yang tersedia. Oleh 
sebab itu upaya yang dilakukan adalah agar peneliti selanjutnya mampu menyampaikan fenomena yang lebih nyata kepada siswa atau peneliti selanjutnya mempertimbangkan media yang akan digunakan. Apabila langkahlangkah model pembelajaran discovery learningdapat dilakukan seefektif mungkin dan dapat dikombinasikan dengan baik dengan media pembelajaran animasi maka model pembelajarandiscovery learningdapat dijadikan salah satu model pembelajaran yang dapat memperbaiki hasil belajar fisika siswa.

Selain itu kesulitan yang dihadapi peneliti adalah siswa belum diajarkan untuk menggunakan alat-alat laboratorium yang digunakan dalam penelitian ini, seperti menggunakan multimeter dan project board sehingga peneliti harus mengajarkan penggunaan alat-alat laboratorium tersebut. Sehingga, pada fase data collection dan data processing siswa masih mengalami kesusahan. Untuk itu peneliti selanjutnya harus mengajarkan penggunaan alat-alat laboratorium yang akan digunakan terlebih dahulu agar dapat menerapkan semua langkah dalam model pembelajaran discovery learning ini dengan baik.

\section{KESIMPULAN DAN SARAN}

\section{Kesimpulan}

Kesimpulanhasil analisis yang dilakukan dalam penelitian ini diperolehnilai rata-rata pretes kelas eksperimen sebesar 23,43dan nilai ratarata postes pada kelas eksperimen yang diajarkan dengan model discovery learning berbasis pendekatan saintifik sebesar 71,71. Sedangkan nilai ratarata pretes kelas kontrol sebesar 23,03 dan nilai rata-rata postes pada kelas kontrol yang diajarkan dengan model pembelajaran konvensional sebesar
54,54. Berdasarkan hasil uji hipotesis menunjukkan bahwamodeldiscovery learning berbasis pendekatan saintifik memberikan pengaruh yang signifikan daripada pembelajaran konvensional dalam meningkatkan hasil belajar siswa pada materi pokok Listrik Dinamis di kelas X semester II SMA Negeri 14 Medan T.P 2014/2015.

\section{Saran}

Berdasarkan hasil dan kesimpulan dalam penelitian ini disarankan bagi guru dan para peneliti selanjutnya agar mempertimbangkan aspek sarana dan prasarana yang memadai serta penyesuaian materi belajar dan waktu belajar yang tersedia agar model ini dapat berjalan dengan baik dan lancar.

\section{DAFTAR PUSTAKA}

Carin, A., dan Sund, B. R., (1964), Teaching Science Through Discovery, Charles E. Merrill Books, Inc., United States, America.

Dahar, R.W., (1989), Teori - Teori Belajar, Penerbit Erlangga, Jakarta.

Hosnan, M,. (2014), Pendekatan Saintifik dan Kontekstual dalam Pembelajaran Abad 21, Penerbit Ghalia Indonesia, Jakarta.

Indarti, Suyudi, A., dan Yogihati, C.I., (2013), Pengaruh Model Discovery Learning terhadap Kemampuan Memecahkan Siswa Kelas X SMAN 8 Malang, Jurnal Pendidikan Fisika Universitas Negeri Malang.

Widiadnyana, I W., Sadia I W., dan Suastra I W., (2014), Pengaruh Model Discovery Learning terhadap Pemahaman Konsep IPA dan Sikap Ilmiah Siswa SMP, Jurnal Program Pascasarjana Universitas Pendidikan Ganesha Singaraja IndonesiaVol : 4 .

Yurahly, D., Darmadi, I W., dan Darsikin, (2012), Model Pembelajaran Guided Discovery 
dan Direct Instruction Berbasis Keterampilan Proses Sains Siswa SMA Negeri 4 Palu, Jurnal
Pendidikan Fisika TadulakoVol. 2 No.2 